\title{
Perception-based Assessment of Ecosystem Services of Abijata-Shalla National Park Wetlands in the Central Rift Valley of Ethiopia
}

Denbel Bedo ( $\sim$ dembocity@yahoo.com )

St Mary's University

Abate Mekuriaw

Addis Ababa University

Amare Bantider

Addis Ababa University

\section{Research Article}

Keywords: wetland ecosystem services, perception, drivers of change, Abijata wetland, Abijata-Shalla Park

Posted Date: January 12th, 2022

DOI: https://doi.org/10.21203/rs.3.rs-1192792/v1

License: (c) (i) This work is licensed under a Creative Commons Attribution 4.0 International License. Read Full License 


\section{Abstract}

Abijata-Shalla Park was established as one of Ethiopia's national parks to safeguard wetlands and ecosystem services (ESS). Some of the ESs that are offered by the wetlands are currently depleting and disappearing rather than being protected. Understanding the drivers behind these changes can help individuals and policymakers design mitigation measures. The objective of this case was to assess ESs and the drivers of change with highlighting on the Abijata wetland. In addition to a household survey and group discussion, personal interviews and field observation were employed to collect data. Using these data, the various ESs were assessed and ranked from 1-10 according to local perception. Grading scales such as very high (-2), high (-1), neutral (0), low (+1), and very low (+2) were employed to analyse the drivers of ESs change. Analyses of the study revealed that some of the ESs, including fish, papyrus, water reeds, hunting and spiritual services, existed before 1991, but have since disappeared from the site. Twenty ESs are available, 11 services pertain to provisioning, followed by 4 regulating, 3 cultural and 2 supporting services. Wetland for cultivation ranked highest, followed by domestic water supply and pasture. All services, with the exception of arable land and pasture, are on the decline. Water abstraction is the primary driver of ESs change, followed by population growth and deforestation. The park existed as a "paper park." Water withdrawals from the Ziway-Shalla sub-basin should be restricted. Instead, focus on water conservation strategies to make better use of abstracted water.

\section{Introduction}

Wetland ecosystems are the most productive natural ecosystems on Earth, next to rain forests (Balliett, 2011). They are described both as "the kidneys of the landscape" because of the functions they perform in the hydrological and chemical cycles, and as "biological supermarkets" because of the extensive food chain and the rich biodiversity that they support (Mitsch and Gosselink, 2015).

Wetlands offer a wide range of benefits to humans. All the benefits that humans obtain from ecosystems are considered as ecosystem services (ESs), which are described in the Millennium Ecosystem Assessment, MEA (2005) as provisioning, cultural, regulating and supporting services.

As per the Ramsar Convention, RC (1971) definition, Ethiopia has different types of wetlands, which have several socioeconomic and ecological benefits. Except for coastal and marine-related wetlands and extensive swamp-forest complexes, all forms of wetlands are found in Ethiopia (Lemlem, 2003). The "Water Tower" of Africa (Leykun, 2003) is often used to describe this country. So far, the country does not have any Ramsar sites. Among the countries bordering Ethiopia, Kenya has six sites, Sudan has three, whereas South Sudan and Djibouti each have one (www.ramsar.org).

The majority of Ethiopia's wetlands are located within the Rift Valley Basin (Jansen et al., 2007; ReaughFlower, 2011). In the country, the basin is known for having huge water potential, which includes four subbasins: Ziway-Shalla (Central Rift Valley (CRV), Lakes), Awassa, Abaya-Chamo and Chew Bahir (Lemlem, 2003). The Ziway-Shalla sub-basin or the CRV sub-basin of Ethiopia is an important region in terms of its 
enormous ESs and enriched biodiversity (Eyasu et al., 2019). The sub-basin, encompasses four major interconnected lakes in its rift valley, namely: Ziway, Langano, Abijata and Shalla.

Lake Abijata and Lake Shalla together form Abijata Shalla National Park (ASNP). The Ethiopian government had proposed it to the RC as a candidate site (Reaugh-Flower, 2011). In terms of the major wetland systems recognized by the RC, the ASNP belongs to the lacustrine wetland and riverine wetland groups (Tefesse, 2008). The lacustrine wetlands are wetland systems pertaining to lakes or lake shores, whereas the riverine wetland system is wetlands along rivers and streams (Balliett, 2011). At the current research site, both systems play a key role in the delivery of the ESs.

Except for the wetlands mentioned above and some other known wetlands in the country, the wetland resources have not been fully documented. However, it is estimated that the country has more than 58 different types of wetlands (Hagose et al., 2014), with an estimated area of $18,587 \mathrm{~km}^{2}(1.5-2 \%)$ of the total land mass of the country (Mekonnen and Yared, 2018).

Despite being the most productive ecosystems on the planet and providing numerous benefits to humans, wetlands are also the most threatened in the Earth's natural environment (The Intergovernmental Panel on Climate Change, IPCC, 2007). In both developed and developing countries, they have been destroyed at an alarming rate (Mitsch and Gosselink, 2015). Depending on the region, $30-90 \%$ of the world's wetlands have already been destroyed or heavily altered in many countries (Getinet, 2017). They are also predicted to decline and disappear at a faster rate in the future, both in terms of area and quality (Shrestha, 2011; Bhatta et al., 2016).

In Ethiopia, the capacity of wetlands to provide ESs has been changing at a rate that is possibly historically unprecedented. As evidenced by numerous studies conducted by scholars (e.g., ReaughFlower, 2011; Tariku and Abebayehu, 2011; Hagos et al., 2014; Yohannes et al., 2017; Ayalew, 2018; Dagne, 2018; Asefa et al., 2018; Fitsum et al., 2019) from all parts of Ethiopia, Ethiopia's wetlands and the resources they provide have declined rapidly in recent decades, mainly as a result of anthropogenic activities being exacerbated by climate change.

The changes in wetland use systems to meet the demands of a growing population for farming, livestock grazing, and human settlement are inducing a shift in the socioeconomic and ecological functions of wetlands (Mekonnen and Yared, 2018; Binyam and Shimales, 2019). Urban market forces are another major driving force. The ever-growing market for various provisioning services (PSs), including fish, fresh water, firewood, and other products like fruit and vegetable farming, are major drivers of depreciation. As per Dagne (2018), the growth of urban areas in the country contributes to deforestation, polluting the environment, and disposing of sewage and garbage into wetlands on the one hand, while simultaneously increasing demand for wetland products in urban areas and neighbouring countries on the other. There is extensive use of chemical fertilizers and insecticides to intensify wetland cultivation, which increases pollution as well as the discharge of sewage into wetlands. Especially since the large-scale farming sites are very close to the wetlands, they easily diffuse the various agrochemicals to the nearby wetlands and 
terrestrial areas, which can be easily drained into wetlands (Hagos et al., 2014). Another pressure is rural unemployment. Rural residents rely on wetland resources to sustain their livelihoods as the rural population is growing faster than rural employment opportunities (Mwita, 2013).

At the national level, Ethiopia has incorporated wetlands policy into its water resources, agriculture, and environmental policies, but it does not have a national standing strategic plan or a specific wetland policy. The absence of a wetland policy and an accountable institution for addressing problems and the delayed ratification of the RC by the Ethiopian government have also contributed to the unrelieved conversion of wetland ecosystems and the degradation of their services (Dagne, 2018; Fitsum et al., 2019). Kebede (2014) further claims that there is also no ESs use policy in the country (e.g., water use policy). This deficiency can lead to unregulated, unsustainable, or unlawful use of water and other wetland resources. For instance, the soda ash factory and upstream flower farm, which were established on the shores of Lake Abijata and Ziway, have been extracting the water from the wetlands with no restrictions.

A number of scholars (e.g., Wondwossen et al., 2017; Yohannes et al., 2017; Binyam and Shimelis, 2019) have argued that Ethiopia's wetlands face many problems as a consequence of the failure to conduct Environmental Impact Assessments (EIA) prior to development projects. The construction of mechanized irrigation systems are good examples. The degradation and loss of wetlands are also exacerbated by the public ignorance of the value of wetlands (they are free and no one owns them) and insufficient recognition of the vital importance of the services that wetlands provide to human well-being (Mekonnen and Yared, 2018), the low involvement of local communities in wetland conservation and management (Ayalew, 2018; Eyasu et al., 2019), and local villagers have no incentive to protect them (Fetsum et al., 2019). Many intellectuals (e.g., Yilma, 2003; Hagos et al., 2014; Getinet, 2017; Eyasu et al., 2019) have observed that Ethiopians have not paid sufficient attention to the need to address the loss and degradation of their wetland resources at either the national or local levels.

One of the most important wetlands in Ethiopia, the wetlands within Abijata-Shalla Park plays a significant role in the livelihoods of local villagers living throughout the sub-basin as well as in the social and economic development of the country (Young, 2012). Currently, this natural heritage is suffering from degradation. Not only do the surface areas of the wetlands fluctuate year to year, but so do the quality and quantity of the ESs they offer. Abijata Wetland (AW), part of the ASNP in Ethiopia's CRV sub-basin, is among the most threatened ecosystems, and its goods and services are being destroyed (e.g., Yohannes et al., 2017; Asefa et al., 2018; Firew and Solomon, 2018; Eyasu et al., 2019). It is predicted that the wetland of Abijata will be completely used up in the next 20 to 50 years if pressures in the CRV sub-basin continue as usual (Jansen et al., 2007). Hence, it is crucial to understand the drivers behind the changes in the wetland of Abijata and its ESs in order to design interventions that take into account positive impacts and minimize negative impacts. In the MEA (2005), a "driver" refers to any factor that changes an aspect of an ecosystem. In this study, factors that influence AW and its associated riverine system and their services. 
The researchers' motivation was to establish a general background and provide science-based information on the wetlands and their ESs for conservation purposes. Our research centred on the following questions: What ESs are currently provided by the park's wetlands? What trend has been witnessed in the availability of ESs historically, pre-1991 and after? What are the drivers for the change?

\section{Materials And Methods}

\section{Study Area}

The CRV of Ethiopia is part of the Great African Rift Valley and lies between $38^{\circ} 00^{\prime}-39^{\circ} 30^{\prime} \mathrm{E}$ longitude and $7^{\circ} 00^{\prime}-8^{\circ} 30^{\prime} \mathrm{N}$ latitude. The area has an arid to semi-arid climate, although the highlands on the eastern and western escarpments of the valley are sub-humid. The sub-basin is endowed with a significant number of wetlands, which could contribute to the social, economical, and ecological development of the country (Jansan et al., 2007).

The park is located within the Ziway-Shalla sub-basin, part of the Ethiopian CRV. The sub-basin includes Lake Shalla and Lake Abijata, separated by $3 \mathrm{Km}$ of mountainous land. Together, they form the ASNP. The park was established in 1970 to protect endemic and endangered wildlife and aquatic birdlife as well as the two lakes and surrounding acacia forests (Jansan et al., 2007). There are two types of ecosystems within the park: aquatic ( $482 \mathrm{~km}^{2}$ covered by lakes, including Abijata and Shalla) and terrestrial $\left(405 \mathrm{~km}^{2}\right)$. In addition to the two lakes, the park has numerous associated hot springs and rivers around the catchments.

Within the park, there are two main rivers: the Bulbula and the Hora Qello River, which both feed Lake Abijata from Lake Ziway and Lake Langano, respectively. Two other rivers, Jido and Dedeba, flow into Lake Shalla, especially during the rainy seasons. Shalla Lake is the deepest lake in the Ethiopian Rift Valley, with a maximum depth of $266 \mathrm{~m}$ (Reaugh-Flower, 2011).

The park offers habitat for wildlife and has served as a wintering site and maintenance station for a large number of birds, including species native to Southern African, Sub-Saharan, and Palaearctic species. As a result, the park became one of the most popular tourist destinations in the country (Kumssa and Bekele, 2014). It was proposed by Birdlife International to be a potential Ramsar wetland and a UNESCO World Heritage Site (Reaugh-Flower, 2011).

The altitude of the park ranges from 1540 to 2075 m.a.s.l., with the highest peak being Mount Fike, which is situated between the two lakes. It is $200 \mathrm{~km}$ from Addis Ababa. Administratively, the area shares fall between the East Shewa (Adami Tullu and Jido Kombolcha, ATJK district- North) and West Arsi zones (Arsi Negelle, AN district-South, and Southeast and west) of the Oromiya regional state (see figure 1). The Hora Kalo river constitutes a boundary between the two districts.

The climate of the ASNP is semi-arid for most of the year, with the rainy season between June and September, the dry season from October to February, and a small rainy season in between. The region 
receives annual precipitation varying from 500 (Langano Lake Weather Station) to $700 \mathrm{~mm}$ (Ziway Lake Weather Station), with a mean annual temperature of $20^{\circ} \mathrm{C}$ (Yohannes et al., 2017).

\section{Data Collection Tools}

Several approaches were employed to collect the primary data, including structured interview (questionnaire), focus group discussion (FGD), key information interview (KII) and direct field observation. The cross-sectional survey was conducted by trained enumerators (Development Agents, DA), while the participatory methods were carried out by a researcher to validate the survey results. Also, secondary sources were used to supplement primary data.

For the household survey, FGDs, and KIls, 1991 served as a reference or benchmark year. Due to the fact that it represents the period after the fall of the Dergue Regime, when the Federal Democratic Republic of Ethiopia (FDRE) becomes empowered. This allows households to easily memorize trends of changes in ESs and possible drivers of past changes. In order to gain a historical perspective on long-term changes in ESs, only community members over 30 years of age were interviewed. They are assumed to have a greater understanding of the foregoing and can provide historical experience.

Questionnaire: Before the actual field data collection, a reconnaissance survey was conducted to verify the validity and reliability of the questionnaire. We checked the questionnaire before conducting the interview to make sure that it produced the anticipated responses, the length of the interview, and the patterns of results. We designed the questionnaire based on the wetland ESs identified by (Stelk and Christie, 2014; Mitsch and Gosselink 2015), with some conceptualization of the research site.

Focus Group Discussions: A FGD was conducted in each Kebele (The smallest administrative unit in Ethiopia) with six to eight individuals of both sexes. The participants of the FGDs were chosen based on their livelihood strategies and their dependence on wetland resources, with the help of local leaders and DAs. The discussions took place with selected knowledgeable people, who had extensive knowledge of the issue under investigation, which consisted of indigenous local leaders, healers, DAs, and other actors, using a checklist of questions. FGDs were conducted to identify existing ESs, trends in ESs change, and the drivers for change.

Key Informant Interview: Individual KIls were carefully identified with the assistance of the heads of households who participated in FGDs, the DAs and members of the Kebele leadership. Twelve key informants were interviewed (two from each Kebele) using an open-ended checklist at times and locations they chose.

Field Observation: Field observations were made at two separate times. The first round of fieldwork took place during the pilot study and was important for a better understanding of the physical setting of the study area, the accessibility of Kebeles for fieldwork, and their proximity to the wetlands of the park. A 
second in-depth field observation was conducted during the data collection period by walking through the wetlands, Kebeles, as well as having informal discussions with local inhabitants.

\section{Sample Frame and Sampling Techniques}

All household heads over 30 years old living in or on the park periphery and who are directly or indirectly dependent on the wetland services of the park were included in the study. A multistage sampling procedure was used to identify the heads of households from whom the data were collected. ASNP was chosen due to the fact that, despite being the only national park in Ethiopia established to protect wetlands, it was and remains one of Ethiopia's most endangered sites (for e.g., Wondwossen et al., 2017; Yohannes et al., 2017; Fetsum et al., 2019; Eyasu et al., 2019), which needed an urgent solution. In the second step, two districts that share a boundary with the park's ecosystems were selected. Within the park, wetlands shared $85 \%$ and $15 \%$ of their boundaries with the AN and ATJK districts, respectively (see figure 1). After consulting with agricultural extension experts from the two districts, the Kebeles located inside or on the periphery of the park and heavily dependent on the park's wetland resources as a source of livelihood were selected in the third stage. Hence, four Kebeles (Shalla Bila, Mude Arjo, Daka Dalu Haran Gama and Gale Kelo) from AN and two Kebeles from ATJK (Desta Abijata and Adansho Boranota) were selected purposely based on their adequate security for data collection, accessibility for fieldwork, and closeness to the Park headquarter. In all, six Kebeles were included in the study. A total of 346 household heads were randomly selected from selected Kebeles based on a probability proportional to their size. A more rigorous, scientific method was used to determine the sample size. This was in order to ensure an approximate representation of the sample. The sample size was computed using Kothari (2004).

As a result of incomplete data from some of the respondents, the response rate for the study was $98 \%$ of the 346 responses expected. Additionally, 12 KIls and 6 FGDs were conducted to validate the findings obtained from the household survey. The household survey took place from July 2020 to September 2020.

\section{Data Analysis}

The gathered data were analysed to assess the different ESs and the drivers of change. The study employed both quantitative and qualitative analyses to achieve its objectives and answer the research questions concerning the problem under investigation.

Content analysis was used to summarize the qualitative data collected through various qualitative methods. The ESs were ranked by FGD participants to determine the top ten most important ESs that the local villagers obtained from the park wetlands. After identifying the key ESs found in the wetlands, participants were asked to assign a score to each service. Six groups, each with six members, participated in the discussion to assign scores for each service. A consensus was reached among each group on the overall score for each ESs, and 10 well-known ESs were selected from the research site. Scores were assigned to the shortlisted services on a scale of 1 to 10 (1 with lowest preference and 10 
with highest preference). Finally, the ranking order of most to least preferred services was determined by summing up the individual marks given for each service by each group that participated in the assessment divided by the number of groups (as in Bhatta et al., 2016; Deka et al., 2019). Ranks were determined based on the perceptions of each group regarding the socioeconomic and environmental benefits of each service. We used the same approach to determine the driving forces behind changes in wetland ESs provision. The top ten drivers of ecosystem change were analysed with a grading scale as very high $(-2)$, high $(-1)$, neutral $(0)$, low $(+1)$, and very low $(+2)$. The grading scale has determined the priority of the different drivers of ecosystem change (Appendix II). The top ten drivers of ESs change were calculated based on the relative scores provided by the groups involved in the discussion (Appendix I).

\section{Results And Discussion}

\section{Ecosystem Services Assessment}

\section{Assessment of ESs prior to 1991}

Local residents were asked for a list of ESs available before the fall of the Dergue regime in 1991. Through household surveys, focus groups, and interviews with key informants, we identified 25 key ESs in the ASNP wetlands. Among them, 15 services belong to the provisioning category, followed by regulating and cultural services (4 for each) and supporting services (2) (Figure 2). The classification of ESs follows the MEA report (2005).

\section{Changes of Ecosystems and their ESs Prior to 1991.}

As determined by the FGDs and key informants, the park's wetlands were reached before 1991 in ESs and biodiversity. One of the park's wetlands, the AW, provided the area's inhabitants with food and income through food production and fishing. The AW once contained many fish, including tilapia (Oreochromis niloticus), which was an important source of animal protein for the locals. The wetland resources of the park were also used for other human needs. The villagers collected fruits, seeds, tubers, roots, and leaves of different plants from the park's wetlands and used them as sources of food as well as traditional medicine. The majority of households obtained water reeds and grass for thatching and foraging from the wetlands. Because the surrounding wetlands were rich in pasture, there was no shortage of feed for their livestock.

As a supporting service, the wetlands provided habitat for wild flora and fauna, as well as a fish nursery (figure 2). In the park, a total of 436 species of birds were recorded (of which 114 were wetland birds) (Tafesse, 2008). A significant part of the park's history was the presence of wetland birds migrating from the Paleo-Arctic during the northern winter. The wetlands in the park served as a stopover for a wide variety of birds, including Lesser Flamingo (Phoeniconaias minor), Greater Flamingo (Phoenicopterus roseus), Northern Shoveler (Spatula clypeata), Pied Avocet (Recurvirostra avosetta), Eastern Yellow-billed Hornbill (Tockus flavirostris), and Great White Pelican (Pelecanus onocrotalus roseus), among others (Jansen et al., 2007). 
During the field, survey opinions were recorded regarding the cultural services of the park. As revealed by villagers, many visitors visit the park to admire the beautiful wonders of birds interacting with their natural environment. The number of bird-watching tourists visiting the park wetlands was high, and many of them stayed long in the area. Meanwhile, the revenue generated from the park was high. Some residents directly benefit from tourists by being tour guides and selling handicrafts, while others indirectly benefit through leisure and entertainment with tourists. Additionally, the park served as a hub for researchers and students from across the world.

\section{Assessing ESs and their Changing Trends since 991}

Interviewees were asked to identify and discuss the history of key ESs that existed prior to 1991 but are currently missing from the site. A total of five key ESs have disappeared from the wetlands. Fish, papyrus, water reeds, and hunting are among the PSs; the fifth is a cultural service, spirituality, or religious practices.

The communities within and around the park, relied heavily upon fish for food and livelihood. The FGD participants stressed that we shouldn't forget the noble use of fish in our lives during the 1983-1985 famine that took place in the country. Many surrounding communities have used wetland products, particularly fish, as safety nets to cope with the stresses caused by drought at that time. They recall that the loss of wetland fish began at the beginning of FDRE's coming to power. Similarly, Reaugh-Flower (2011) noted that there have been no fish or fishing activities in the AW since 1993.

The wetlands in the park were relatively overgrown with wetland vegetation. The FGD participants informed us that local residents were harvesting wetlands vegetation such as papyrus (Cyperus papyrus), water reeds like Typha (Typha latifolia), Schoenoplectus (Schoenoplectus corymboses), and other thatching materials to meet various local needs. Papyrus was one of the most important wetland vegetation types in the area. Besides its celebrated use, it was also used as a rural energy source (firewood), food, and animal feed. Among the most well-known uses of the papyrus plant in the area was the construction of the unique boat (locally known as "Jabala") for travel on the lacustrine wetland, the wetland of Abijata. Papyrus locally known as "Jabalo". Although the plant disappeared from the site by this time, it is still present in small quantities in the wetlands of Tana and Ziway.

There have been some hunting practices in the park's wetlands since 1973, despite the fact that hunting in the protected area was not permitted. The core reasons for hunting wildlife by the villagers were for meat, recreation, to remove predators that can be dangerous to humans, domestic animals, or crops. The villagers hunted animals like hippopotamuses (Hippopotamus amphibious) for teeth, meat, and skins. There is no hunting at the moment because the wild animals that lived in the Abijata lake and river forest have now moved to another location. A very few wild animals left in the park. Many animals, including hippopotamus, disappeared from the site.

Historically, at the current study site, local villagers were connected to natural resources for their spiritual purposes. The most common place was the wetlands in the park. Participants in FGDs and KIls reported 
that the wetlands of the park were the most important places for spiritual activities in the past, but spiritual services are no longer held there.

\section{The Most Important Services as Perceived by Local Communities}

Based on the FGD participants' feedback, the top 10 services were identified and ranked (Table 2). The wetlands for cultivation (AW) were ranked first. A riverine wetland, particularly the Bulbula river for supplying drinking water, followed by a lacustrine wetland (Abijata) for grazing livestock. Six out of ten services were PSs, followed by two regulating services and cultural and supporting services (one for each service). These services were ranked according to their use in the household and/or their ability to sell them on the market for financial returns. As well, the cultural ESs that households perceive and appreciate at the community level were also used to rank services.

Table 1

The Top 10 Services with details about their Current Status (compared to the past 30 years) as Perceived by Local Communities

\begin{tabular}{|llll|}
\hline Services & Ranking & $\begin{array}{l}\text { Trends of change } \\
\text { (increasing/decreasing/no change) }\end{array}$ & $\begin{array}{l}\text { Source/s of the } \\
\text { services }\end{array}$ \\
\hline Land for cultivation & 1 nd & Increasing & $\begin{array}{l}\text { Abijata and } \\
\text { riverine }\end{array}$ \\
\begin{tabular}{|l} 
Water for domestic and \\
livestock use
\end{tabular} & 2nd & Decreasing & $\begin{array}{l}\text { Abijata and } \\
\text { riverine }\end{array}$ \\
\hline Grazing land & 3rd & Increasing & Abijata \\
\hline Salt and sand mining & 4th & Decreasing & Abijata \\
\hline Recreation and Tourism & 5 th & Decreasing & Abijata \\
\hline Groundwater recharge & 6th & Decreasing & $\begin{array}{l}\text { Abijata and } \\
\text { riverine }\end{array}$ \\
\hline Medical resources & 7th & Decreasing & Riverine \\
\hline Habitat for aquatic birdlife & 8th & Decreasing & $\begin{array}{l}\text { Abijata and } \\
\text { riverine }\end{array}$ \\
\hline Water for irrigation purpose & 9th & Decreasing & Riverine \\
\hline Microclimate regulation & 10th & Decreasing & $\begin{array}{l}\text { Abijata and } \\
\text { riverine }\end{array}$ \\
\hline Source: FGDs (2020) & & & \\
\hline
\end{tabular}

As shown in Table 1, all services, except arable land and pasture land, are decreasing. The following are ten services that the local community has deemed the most popular, accompanied by detailed information about their current status (compared to the past 30 years):

\section{Land for cultivation}


Wetland use for farming was identified as the most important services by the participants in the focus group and KIls. Part of the AW has been converted into farmland. Those households living nearby the wetland have been practicing extensive agricultural systems (without chemical fertilizer and high yield varieties use) as a direction for enhancing crop production. Shrinking the wetland area enable some of the farmers to gain additional farmlands along shrinking wetland area every year. However, the erratic rainfall and poor soil fertility along with high alkalinity of the moist soil result in poor crop yields in the area. This is very noticeable in the south and southeast part of the wetland of Abijata in particular, along Galeef Qello and Shalla Billa Kebeles as they are located in the heart of the park. We also observed bare land along AW (Figure 3).

Participants in the discussion pointed out that riverine wetlands are also subject to intensive farming, in addition to extensive farming use along the lacustrine shoreline. The Bulbula river has recently been used by a few households for irrigation during the summer. This practice is limited to Dest Abijata Kebele which is located at the inlet of the Bulbula River to AW. Along the lacustrine wetland, the main crops are maize (Zea mays), followed by haricot bean (Phaseolus vulgaris) and sorghum (Sorghum sp), whereas tomato (Solanum lycopersicum) and onion (Allium cepa) are among the main crops grown along the river Bulbula.

\section{Water for Domestic and Livestock}

Riverine Wetland

The Bulbula River, which originates from Lake Ziway, is the main source of fresh water for AW as well as for the local residents living within and outside the park. It is the most accessible drinking water supply for the villagers of Desta Abijata and Adansho Boranota Kebeles. Livestock keepers in the area are also dependent directly on this river for their livestock water needs. The river may dry for some months. Villagers access water during the dry season (October to February) by digging holes in the river or drawing water from alternative sources (such as Lake Langano and the Hora Qallo River).

The Hora Qello River is salty and not as widely used as the Bulbula River. However, this river has been used for drinking (by livestock and wildlife), washing, and swimming. Local villagers have noted a substantial change in the volume of water discharged by the two rivers into AW.

Lacustrine wetland: Wetland of Abijata

Ethiopia's AW is an alkaline wetland (Tenalem, 2002). Due to the alkaline nature of the wetland, it is impossible to extract water for irrigation and drinking. A conversation with villagers revealed that they prefer the wetland for washing clothes because they think it has the property of detergent. Yet, the water from AW is used as a raw material for the production of soda ash.

Over the past four decades, the size of the lake Abijata, including its resources, has drastically shrunk. Measurements from satellite images show that the overall lake cover has decreased from $198.4 \mathrm{~km}^{2}$ in 
1972 to $131.8 \mathrm{~km}^{2}$ in 2015 (Binyam and Shimelis, 2019). This means that the Lake lost $66.6 \mathrm{~km}^{2}$ (33.59\%) of its surface area between 1972 and 2015.

Lake Shalla has a similar but considerably more salty and alkaline chemical composition than Lake Abijata (Tenalem, 2002). The lake is the least researched and understood lake in the country and the most exceptionally deep soda lake in Africa, with a maximum depth of $266 \mathrm{~m}$ (Reaugh-Flower, 2011). It is neither suitable for irrigation nor for domestic use.

\section{Grazing Land}

Grazing livestock around wetlands is a common practice in the study area. The shore of Abijata serves as an area where local and some nomadic pastoralist communities communally graze their animals (figure 4). During the winter months, many cattle keepers migrate to the wetland of the park (Abijata) to graze their herds.

\section{Resource Extraction: sand and salt mining}

Besides farming and grazing, villagers also harvest minerals like sand for construction and salt (locally known as "Boji") for feeding their livestock from the shores of AW. Some villagers illegally extract the minerals to earn an income and maintain their livelihood by selling the resources to other parts of the country.

\section{Recreation and Tourism Services}

FGD participants mentioned that the creation of employment opportunities for park tour guides and scouts can be seen as the benefit the park brings to the villagers. Tourism also gives villagers a chance to broaden their knowledge and horizons by interacting with tourists. The interaction between tourists and local villagers leads to an increased interest in education and participation in local wage-earning activities. As a result of the decline in wetland birds, fewer people are visiting the park to watch birds.

\section{Groundwater Recharge}

Surface and ground water are recharged by rainfall that seeps into them (Tenalem, 2002). ASNP wetlands are hydrologically connected to other CRV lakes, rivers, and groundwater, so they contribute greatly to groundwater recharge. Groundwater, in turn, provides water for drinking and maintenance of streamflow and reservoir levels. The FGD participants noted that access to groundwater is easier in the summer, but it is more difficult in the winter. Likewise, the water refill service is well received by the locals.

\section{Medical resources}

Water sources like Shalla hot springs and the two lakes, as well as traditional medicinal plants grown in the park, bear medicinal value. The riverine forest is the main place where medicinal plants are collected by traditional healers and the elderly. The most useful traditional medicinal plants identified by FGDs and key informants, including healers, are Ocimum urtitolum, Solanum incanum, Croton macrostachys, Euphorbia scoparia, Aloe spp, Kalanchoe spp, Balanties aegyptica, Achyrantes aspera, Cussonia holstii, Clerodendron myricoides, Asparagus spp, and Capparis micrantha, among others. Local healers use 
these medicinal plants to treat various diseases like dog bites, tapeworm infections, tooth infections, and other acute and chronic diseases.

Wetland water has been and continues to be used as a local remedy. The locals believe that the water from Lake Abijata and Lake Shalla can cure fungal infections of the skin (Dermatophytes), relieve itching and wounds, and can also eliminate dandruff and scalp diseases (Tinea capitis, or ringworm of the hair). As described by the interviewees, water from the lakes is also used to treat livestock inches and wounds.

\section{Habitat for Aquatic Bird Life}

In the first place, the park was established to protect and conserve a large number of water birds that use the wetland of Abijata as a feeding site and Lake Shalla as a breeding site. As per Zerubabel's (2018) report, the park was home to about 436 bird species, which makes up almost $52.5 \%$ of the country's bird population. In recent years, the number of earlier species of birds has declined due to a lack of vegetation and fish in wetlands, which provide food for both wetland and terrestrial birds.

\section{Irrigation practice}

There are a few members and non-members of the village who depend on the river Bulbula for smallscale irrigation prior to entering the AW.

\section{Microclimate Regulation}

Climate change could change wetlands forever, but in turn, healthy wetlands can also help to mitigate the impact of climate change via regulating, capturing and storing greenhouse gases, GHGs (Balliett, 2011). Their dense wetland vegetation, algal activity and soils can regulate processes such as decomposition, which generate GHGs (Mitsch and Gosselink, 2015). Local people were aware of the benefits that vegetation in wetlands provided for maintaining local conditions, as people wanted to use shade trees for themselves and their livestock.

\section{The Drivers of Changes in ESs}

There have been so many arguments and propositions put forward to explain the drivers that contribute to the current status of the park's wetlands and its ESs, in particular the lacustrine wetland of the park. The key drivers of change in wetland ESs over the last 30 years have been identified through analysis of household surveys, focus groups, and KIls. From analysing the FGD participants' responses, we identified seven direct and three indirect drivers of ESs changes (Figure 5). In the study, water abstraction (100\%) was identified as the principal threat, followed by population growth (86\%) and deforestation (85\%), as well as climate change (67\%) and lack of active involvement of local villagers in conservation practices $(61 \%)$ as other important factors.

Each of these determinants of ESs change is discussed below:

\section{Intensive Water Abstraction}

There has been a rapid decline in Lake Abijata's water level due to the increased abstraction of water from the lake for soda ash production as well as from its main feeder river, the Bulbula river, for irrigation and 
domestic use.

There has been extensive irrigation around Ziway Lake and its two tributaries, the Katar and Meki Rivers (Jansan et al., 2007). As a result of this, there is a considerable reduction in the amount of water flowing into Lake Ziway, which is the primary source of the river Bulbula. Apart from small-scale irrigation, the expansion of large-scale farming projects along the shores of Lake Ziway and Bulbula River for horticulture, floriculture, and vegetation production consumes a large amount of water and releases chemical pollutants into the water. Certain farming projects divert water from the Bulbulaa river in the dry season, thereby preventing the river from discharging into Lake Abijata.

The water from upstream sources is also used for domestic consumption and livestock watering. This resulted in a drastic decline in the water level of Lake Abijata, as the Bulbula River discharged less water into it.

The Abijata soda ash company is another water user. In spite of the fact that the water of AW is unsuitable for domestic use and irrigation, it is a major raw material in soda ash production. The company was established by the Ethiopian government in 1985 on the shores of the Abijata lake to produce soda ash from sodium bicarbonate $\left(\mathrm{NaHCO}_{3}\right)$ dissolved in wetland water. Sodium bicarbonate is left behind after the wetland water is pumped into 17 artificial evaporation ponds, which are prepared for this purpose. When sodium bicarbonate is heated, it breaks down into sodium carbonate (also known as soda ash $\left(\mathrm{Na}_{2} \mathrm{CO}_{3}\right)$ ), water and carbon dioxide (Jansen et al., 2007). The official production capacity of the company is 20,000 tons of soda ash per year, but its maximum production was about 7,500 tons in 2001 (Reaugh-Flower, 2011). The company produces an average of 4,500 tons of soda ash every year, with a water consumption of $150 \mathrm{~m}^{3}$ per ton (Vilalta, 2010).

Since water discharged from the wetland into the ponds does not return to the wetland, the shore of Lake Abijata has receded for years. The fall in the water level of Lake Abijata, coupled with the fact that the shore of the lake has moved far from the pumping station (shrinking to the centre), has resulted in soda ash production being as low as it has ever been.

The company is targeting to produce 200,000 tons of soda ash per year, using $30,000,000 \mathrm{~m}^{3}$ of water extracted from Lake Shalla rather than Lake Abijata (Reaugh-Flower, 2011). In light of the company's production plan, the production of soda ash from Shalla Lake water is a future threat.

Since the company's inception, the depth, volume and size of the AW has declined along with its resources. According to Reaugh-Flower (2011), fish had vanished after eight years of the soda ash company's establishment. As noted by Jansan et al. (2007), the most likely reasons for fish disappearances were: diminishing wetland water levels; reduced breeding grounds for tilapia; Abijata's salinity is above the tolerance range for tilapia; toxins and pesticides in the water that limit fish and/or algal growth; and osmotic stress as a result of high salt concentrations, among others.

\section{Population Growth}


Even though the protected area, as a conservation tool, is seen as one way to buffer ESs and biodiversity against threats (UNDP, 2013), the ASNP existed largely as a "paper park," a protected area in name only (Reaugh-Flower, 2011). Although the law says the opposite, this protected area is open to villagers. A portion of the park's ESs, which it was formed to protect, have already been lost. Since the pressure of the rural population is greater than the possibility of protecting the natural resources from exploitation.

The indigenous local communities lived in the park before it was proposed as a national park (Young, 2012), and have relied on the goods and services it provides. The human population in the park rose from 2,820 in 1971 to 55,000 in 2010, almost 20 times higher (Reaugh-Flower 2011), and rose to 60,000 by 2020. Since 1971, not only has the human population in the park increased, but the livestock population has also increased, from 30,410 in 1971 to 202,644 in 2010 (Reaugh-Flower, 2011), the number rose to 300,000 in 2020. Increasing human numbers inside the park and in its vicinity have led to an increase in the number of livestock needed to feed the fast-growing population. The simultaneous increase in the number of people and livestock has accelerated the exploitation of wetland resources by local inhabitants to sustain their survival and that of their livestock.

\section{Deforestation}

Deforestation is another key contributor to the current state of the park's wetlands. Although legally prohibited, acacia trees and other riverside trees have been harvested by villagers for firewood and house construction. The FGD participants observed that while some villagers collect wood for their own use, others produce charcoal to sustain their families.

Illegal logging in the park for construction, firewood, and charcoal production, among other things, caused a decline in woody vegetation which could induce changes in local atmospheric temperatures, precipitation, and soil erosion. Severe soil erosion led to severe siltation, which resulted in a decline in the size of Abijata Lake. In that regard, illegal logging is a major threat to the park.

\section{Climate Change}

Well-protected areas can ensure biodiversity and ESs conservation and also provide a valuable buffer against the impacts of climate change (World Bank, 2010). Healthy wetlands serve as mitigation and adaptation mechanisms for climate change (Turpie et al., 2010). Wetlands are a mitigation resource due to their ability to trap and store GHGs. They also contribute to adaptation because they offer services that can assist individuals in adapting to existing and future climate risks.

Despite being part of the solution to climate change, wetlands are one of the ecosystems most affected by even slight changes in the climate and the resulting changes in hydrological patterns (Mitsch and Gosselink, 2015). Higher temperatures, for example, can increase evaporation from soil and wetland surfaces and transpiration from vegetation. The quantity of water and the vegetation cover that protects wetlands can both suffer from a decline in precipitation. As evidenced by Tenalem (2002), climatic change and variability, in particular the drastic reduction of precipitation in the sub-basin since the 1960s, have adversely affected the AW. The wetland is especially vulnerable to climate change since it is shallow in depth and lies in a lowland environment. For instance, Lake Chad, was once the sixth largest lake in the 
world, but due to drought since the 1960s, its size has been reduced to $1 / 10$ of its original size (Onuoha, 2009).

Human activities in the sub-basin have significantly exposed wetland ESs to the adverse impacts of climate change and variability. As a result of a combination of weather changes and human pressure, the AW has shrunk along its ESs and feeder rivers.

\section{Lack of Active Involvement of Local Communities in Conservation Practices}

The designation of protected areas alone does not ensure the protection of natural ecosystems within their boundaries (World Bank, 2010). The participation of wetland users in wetland conservation and management is crucial for extenuating the problems related to wetland ecosystems. Local users are the sole owners as well as the protectors of their resources (Shrestha, 2011).

At the current research site, local communities rely on wetland resources for their subsistence and economic well-being but do not participate in their conservation and management. The focus groups and key stakeholders report that the local villagers are not involved in conservation activities. A portion of the park's revenue is not used to expand the park's capacity or to improve the livelihoods of surrounding populations. There is a perception among most villagers that the park belongs to the government. As a result, communities in the area may be less willing to embrace and collaborate with conservation efforts. Participants also reported that there was no clear demarcation between wetlands and other types of land use. This allows people to overexploit ecosystem resources and convert wetlands as they see fit.

\section{Conflict Over Resources}

Despite the fact that expanding the coverage of protected areas and involving local communities in these efforts can be considered as one of the most effective methods to improve the resilience of nature and people to climate change, increase tourism revenues, and create employment opportunities for some local villagers, the communities in and around ASNP have their own economic interests that conflict with the objectives of the protected areas. Local villagers were asked in the household survey what they liked about the future of the park, and the results are shown in the Table 2 below.

Table 2

Local villagers' preference for the park area

\begin{tabular}{|lll|}
\hline Future preference of the area of ASNP & No. of respondents & Percent \\
\hline Well protected Park & 8 & 2.4 \\
\hline Farmland & 265 & 78.1 \\
\hline Communal Grazing land & 6 & 1.8 \\
\hline Farm and Grazing Land & 60 & 17.7 \\
\hline Total & 339 & 100 \\
\hline Source: Survey Data (2020) & & \\
\hline
\end{tabular}


The majority of respondents (about 97.6\%) prefer to own farmland, grazing land, or both, rather than protect the area.

The Ethiopian Wildlife Conservation Authority (EWCA) needs to safeguard the park by prohibiting people from residing there and taking advantage of its resources. Local villagers, on the other hand, prefer to use the area for settlement houses, farming, and pastures without retaliation, resulting in a conflict between the villagers and the park management. Residents were asked whether or not they were happy with the existence of the protected area. Majorities of residents are disappointed by the Park's existence.

Table 3: Are you happy with the existence of the protected area?

\begin{tabular}{|llll|}
\hline & & No. of respondents & Percent \\
\hline Are you happy with the existence of the park? & No & 329 & 97.1 \\
\cline { 2 - 4 } & Yes & 10 & 2.9 \\
\cline { 2 - 4 } & Total & 339 & 100.0 \\
\hline Source: Survey Data (2020) & & & \\
\hline
\end{tabular}

As seen in Table 3, the majority of households (about 97\%) were unhappy with the park's existence.

Every villager requires a land certificate as a legal basis. To date, however, no land certificates have been issued to the park's residents. Uncertainty over property rights and a lack of ownership have resulted in the unsustainable use of park resources. According to Shimelles et al. (2009), households without secure ownership of their land won't invest in land development, and won't utilize agricultural inputs effectively. Farmers' access to credit, which is necessary to improve agricultural practices, is also limited due to insecure land tenure or absence of land ownership. Farmers used extensive farming practices as a result of the circumstances stated above, which increased rivalry among farmers to expand the extent of arable land from the park's wetlands in their struggle for survival.

\section{Overgrazing}

Due to the availability of water and moisture, many crop producers and livestock keepers have shifted their attention to wetlands where they can cultivate crops and graze their livestock. As the number of livestock increases, wetland services are needed for pasture and drinking water for livestock. Overgrazing of rangeland (wetlands) in the park is increasing the loss of vegetation coverage. As soil and vegetation become disturbed, wetlands rapidly lose their wetland properties.

\section{Pollution and other Sewage}

Besides small-scale irrigation, several greenhouse flower companies have been established along the shores of Lake Ziway and the Bulbula river. These companies have adopted the practice of prolonging growing seasons through irrigation to generate higher levels of productivity from relatively smaller areas. The practices often involved the introduction of excess fertilizers, chemicals, and frequent tillage. These not only affect the ecological characteristics of wetlands and wetlands fauna and flora, but also the 
quality of drinking water supplied from the wetlands as a result of the chemical pollution discharged from the nearby irrigated commercial farm.

The Bulbula River accumulates pollutants from adjacent areas through the intentional or unintentional discharge of wastewater and farm inputs. The loss of aquatic biodiversity and ESs is accelerated by increasing pollution loads. For example, as Jansan et al. (2007) pointed out, an increase in pollutant loads in Lake Abijata was the primary cause of the disappearance of fish-feeding algae.

\section{Resource Extraction: Sand and Salt Mining}

The absence of other economic options led some villagers to engage in maladaptive strategies. The AW's shoreline is exploited by some villagers for sand and salt extraction as an income and a survival method. As a result of these activities, the wetland shoreline suffers from erosion.

\section{Siltation}

Siltation from tributary rivers, especially through the Bulbula River, prevents water from entering the lake despite most of it being deposited at the base of upstream lakes (Ziway and Langano). This reduces the size and resources of the AW.

\section{Conclusions}

Before 1991, the park's wetlands, particularly the AW, supplied substantial ESs, including fish, to local villagers who lived in and near the park. Local villagers had access to thatching materials and traditional medicine from the wetlands. Some riverine forest and wetland areas were used as a source of traditional medicine, and water reeds like Typha and Schoenoplectus were commonly used to thatch roofs. Their livestock had plenty of pasture around the wetlands, so they did not run out of feed.

Some ESs, including fish, papyrus, water reeds, hunting, and spiritual practices, existed before 1991, but are currently missing from the site. Although some ESs have been lost, the park's wetlands continue to supply a variety of goods and services. Eleven of the 20 ESs provided by wetlands are PSs, followed by four regulating, three cultural, and two support services. The use of wetlands for cultivation ranked highest, followed by domestic water supply and pasture. All services, excluding arable land and pasture, have a declining trend in the study area. The ecosystems of the park are deteriorating to an alarming extent, and as a result, not only is it losing its tourist appeal, but also its status as a Ramsar site will be waning.

There are many factors contributing to the current condition of the wetlands. In addition to anthropogenic factors like water abstraction, population growth, and deforestation, there are also natural factors like climate change. One cause of Lake Abijata's depletion is the Abijata Soda Ash Company. In the sub-basin, anthropogenic drivers have exposed the park's wetlands to the harsh impacts of climate change. Climate change, on the other hand, has exacerbated the wetlands' deterioration by weakening their natural resilience. 
Despite the villagers' perception that the aforementioned factors are most explicitly responsible for the degradation of the wetlands, notably the AW and its services, the absence of a wetland policy and an accountable institution in the country has also contributed to the park's wetlands' constantly changing.

Designation of protected areas alone does not guarantee protection of the natural ecosystems within their boundaries. Initiating community-based participatory wetland management practices like those of forest management practices, which are being practiced in certain areas of the country and are showing success, can be a role model. This can be achieved through Indigenous mutual-aid associations, such as "Idir" that will allow for sustainable management of this naturally occurring resource.

The CRV Wetlands Replenishment Project/Program, which primarily focuses on ecological restoration of Abijata-Shalla Park wetlands with the objectives of rehabilitating the wetlands and their ESs and biodiversity, and safeguarding them for present and future generations, should start as soon as possible as it assists the recovery of an ecosystem and its ESs. Identify, ratify, and use international agreements to support these objectives (e.g., the RC). A wetland policy that guides the use of ESs in the country is also urgently needed.

Restrict any increase in water withdrawal in the Ziway-Shalla sub-basin, as this will have a negative impact on the water level of AW due to their hydrological connection. Instead, focus on water conservation strategies (e.g., closed-irrigation systems, drip irrigation, capturing and storing rainwater, watering at night to slow down evaporation, growing drought-tolerant crops, conservation tillage, rotational grazing, and farm systems) to make better use of abstracted water. To that end, integrated subbasin-wide water resource management, with the participation of all stakeholders, should be the cornerstone of safeguarding the park's wetlands.

To trade-off destructive socioeconomic activities within the park, initiating conservation-livelihood enhancement tools like Payments for ESs (PES) schemes as an alternative for wetland ESs conservation through incentive mechanisms to local communities is essential. This will help to achieve a win-win strategy to satisfy both human welfare and ESs protection within the park.

The Soda Ash Company plans to use Lake Shalla because Lake Abijata's water level has reached a point where pumping is no longer practicable. This will damage nature's gift to humanity. We should stop repeating the tragic mistake of AW.

There are still certain difficulties to be investigated, particularly on Lake Shalla. Lake Shalla is the deepest, most alkaline lake in Ethiopia's Rift Valley. It has the potential to produce methane. To the best of the researchers' knowledge, the current status and socioeconomic value of the lake have never been researched. In Rwanda, methane from Lake Kivu is utilized to generate electricity, but it is unknown whether the amount of methane found in Lake Shalla is sufficient. It's critical to pay close attention to this.

\section{Declarations}




\section{Author Contributions:}

All the authors made substantial contributions to the conception and design of the study. Denbel Bedo performed tool development, data collection, data analysis, and wrote the draft paper. Abate Mekuriaw and Amare Bantider guided the research and reviewed the manuscript. All authors have read and agreed to the published version of the manuscript.

\section{Data Availability}

The datasets used and/or analyzed during the current study are available from the corresponding author on reasonable request.

\section{Funding:}

The authors declare that no funds or other support were received during the preparation of this manuscript.

\section{Conflicts of Interest:}

The authors declare no conflict of interest.

\section{Acknowledgements:}

The authors would like to express their gratitude to the households for sharing their local knowledge, the enumerators who carefully conducted the household surveys, and the experts at two district offices of agriculture for their time and information.

\section{References}

1. Asefa A, Mengesha G, Sori T, Mamo Y (2018) Local and landscape level effects of land use change on bird diversity in Abiata-Shalla Lakes National Park, Ethiopia. Afr J Ecol 01:08

2. Ayalew W (2018) Ecological conditions and ESs of wetlands in the Lake Tana Area, Ethiopia. Ecohydrology \& Hydrobiology, Vol. 18: 231-244

3. Balliett JF (2011) Wetlands: environmental issues, global perspectives. M.E. Sharpe, Inc., p 154

4. Bhatta LD, Chaudhary S, Pandit A, Baral H, Das P (2016) Ecosystem Service Changes and Livelihood Impacts in the Maguri-Motapung Wetlands of Assam, India. 5:01-1415

5. Binyam TH, Shimelis G (2019) Spatial and Temporal Lake Level Change of Lake Abijata, Ethiopia: A Remote Sensing Approach. Environ Anal Eco stud 6(1):592-597

6. Dagne T (2018) Preliminary Survey of Wetlands in Ethiopia: Threats, Extent of Degradation, and Future Perspective: A Review Paper. Journal of Ecology of Health \& Environment; 6(2):93-98

7. Deka S, Tripathi OP, Paul A (2018) Perception-based assessment of ecosystem services of Ghagra Pahar forest in Assam, Northeast India. Geology, Ecology, and Landscapes. 
8. Eyasu E, Weldemariam S, Bereket T, Wondwosen G (2019) Impact of land use/cover changes on lake ecosystem of the Ethiopian central rift valley. Cogent Food \& Agriculture 5:1595876

9. Firew B, Solomon E (2018) Challenges to National Park Conservation and Management in Ethiopia. Journal of Agricultural Science; 10(5): 52-61

10. Fitsum D, Feyera S, Dawit D (2019) Determinants of household wetland resource use and management behavior in the Central Rift Valley of Ethiopia.Society for Environmental Sustainability,01-15

11. Getinet S (2017) Status of Wetland Ecosystems in Ethiopia and Required Actions for Conservation. Journal of Resources Development and Management 32:92-100

12. Hagos G, Temesgen G, Mehari A (2014) Wetland Degradation in Ethiopia: Causes, Consequences, and Remedies. Journal of Environment and Earth Science; 4(11): 40-48

13. IPCC (2007) Climate Change: Impacts, Adaptation, and Vulnerability. Contribution of Working Group II to the 4th Assessment Report of the Intergovernmental Panel on Climate Change. Cambridge University Press, Cambridge, UK, p 976

14. Jansen H, Hengsdijk H, Legesse D, Ayenew T, Hellegers P, Spliethoff P (2007) Land and water resources assessment in the Ethiopian Central Rift Valley; Project: ecosystems for water, food, and economic development in the Ethiopian Central Rift Valley. Report by Wageningen. Alterra, Wageningen, $\mathrm{p} 83$

15. Kebede K (2014) Action, inaction and environmental destruction: Socionatural determinants of the disappearance of Lake Haromaya, Eastern Ethiopia. Research Journal of Agriculture and Environmental Management; 3(8): 361-369

16. Kothari (2004) Research Methodology: Methods and Techniques, 2nd edn. New Age International (P) Ltd., Publishers, New Delhi

17. Kumssa T, Bekele A (2014) Attitude and perceptions of local residents toward the protected area of Abijata-Shalla Lakes National Park (ASLNP), Ethiopia. J Ecosysem \& Ecograph; 4(1): 01-05

18. Lemlem S (2003) Biodiversity potential and threats to the southern Rift. Valley lakes of Ethiopia

19. Leykun A (2003) The distribution and status of Ethiopian wetlands: an overview. Wetlands of Ethiopia: Proceedings of a seminar on the resources and status of Ethiopia's wetlands.

20. Mekonnen G, Yared W (2018) "Reversing the Degradation of Ethiopian Wetlands": Is it Unachievable Phrase or a call to Effective Action? Int. J Environ Sci Nat Res. 14(5): 001-011

21. Millenium Ecosystem Assessment (MEA) (2005) Ecosystems and human well-being: Wetlands and Water. Synthesis. World Resources Institute, Washington, DC.

22. Mitsch WJ, Gosselink JG (2015) Wetlands. 5nd Edition. John Wiley and Sons, Hoboken, New Jersey. 702pp

23. Mwita EJ (2013) Land Cover and Land Use Dynamics of Semi Arid Wetlands: A Case of Rumuruti (Kenya) and Malinda (Tanzania). J Geophys Remote Sensing S1:001. doi:10.4172/2169 0049.S1001 
24. Onuoha FC (2009) Environmental Degradation, Livelihood and Conflicts: the Implications of the Diminishing Water. Resources of Lake Chad for North-Eastern Nigeria

25. Reaugh-Flower K (2011) Abijata-Shalla Lakes National Park. Assessment of Factors Driving Environmental Change for Management Decision-Making. Report for the Ethiopian Wildlife Protection Authority's Sustainable Development of the Protected Area System of Ethiopia Program. $81 \mathrm{pp}$

26. Shimelles T, Zahidul IKM, Parviainen T (2009) Effects of land tenure and property rights on agricultural productivity in Ethiopia, Namibia, and Bangladesh. University of Helsinki, Discussion Papers No. 33

27. Shrestha U (2011) Community participation in wetland conservation in Nepal. J Agric Environ 12:140-147

28. Stelk MJ, Christie J (2014) Ecosystem Service Valuation for Wetland Restoration: What It Is, How to Do It, and Best Practice Recommendations. Association of State Wetland Managers, Windham, Maine

29. Tafesse K (2008) An integrated assessment of ESs and stakeholder analysis of Abijata Shala Lakes national park, Ethiopia. MSc Thesis in Environmental Sciences. Wageningen University

30. Tariku M, Abebayehu A (2011) The driving forces of Boye wetland degradation and its bird species composition, Jimma, Southwestern Ethiopia. Journal of Ecology and the Natural Environment; 3(11):365-369

31. Tenalem A (2002) Recent changes in the level of Lake Abiyata, central main Ethiopian Rift Valley. Hydrol Sci J 47(3):493-503

32. Turpie J (2010) Lannas k. In: Scovronick N, Louw A (eds) Wetland Valuation. Vol. I: Wetland Ecosystem Services and Their Valuation: A Review of Current Understanding and Practice. Limpopo Province, South Africa, pp132

33. UNDP (2013) Sustainable Development of Protected Areas: Climate Resilient Green Growth Unit. Boosting Conservation Efforts to Safeguard Ethiopia's Biodiversity, Ecosystems, and Ecologica Processes

34. Vilalta ER (2010) Water resources management in the central rift valley of Ethiopia. MSc thesis, Barcelona, Spain

35. Wondwossen G, Bereket T, Weldemariam S, Eyasu E (2017) Effect of Land Use/Cover Changes on Ecological Landscapes of the Four Lakes of Central Rift Valley Ethiopia. Journal of Environment and Earth Science; 7(12): 28-45

36. World Bank (2010) Convenient Solutions to an Inconvenient Truth: Ecosystem-Based Approaches to Climate Change. The World Bank, Washington, DC

37. Yilma A (2003) Wetlands of Ethiopia: an introduction. Proceedings of a seminar on the resources and status of Ethiopia's wetlands, Nairobi, Kenya. 116 pp

38. Yohannes H, Mohammed A, Elias E (2017) Land Use/Land Cover Dynamics and Its Impact on Biodiversity Resources in the Abijata Shalla National Park, Central Rift Valley Lakes Region, Ethiopia. 
Environ Sci Indian J.; 13 (5): 01-14.

39. Young J (2012) Ethiopian Protected Areas A 'Snapshot'. A reference guide for future strategic planning and project funding

40. Zerubabel W (2018) Eco-Tourism Potentials of Abijata-Shalla Lakes National Park (ASLNP), Central Rift-Valley of Ethiopia. Journal of Tourism, Hospitality and Sports; Vol 37:2312-5179

\section{Figures}

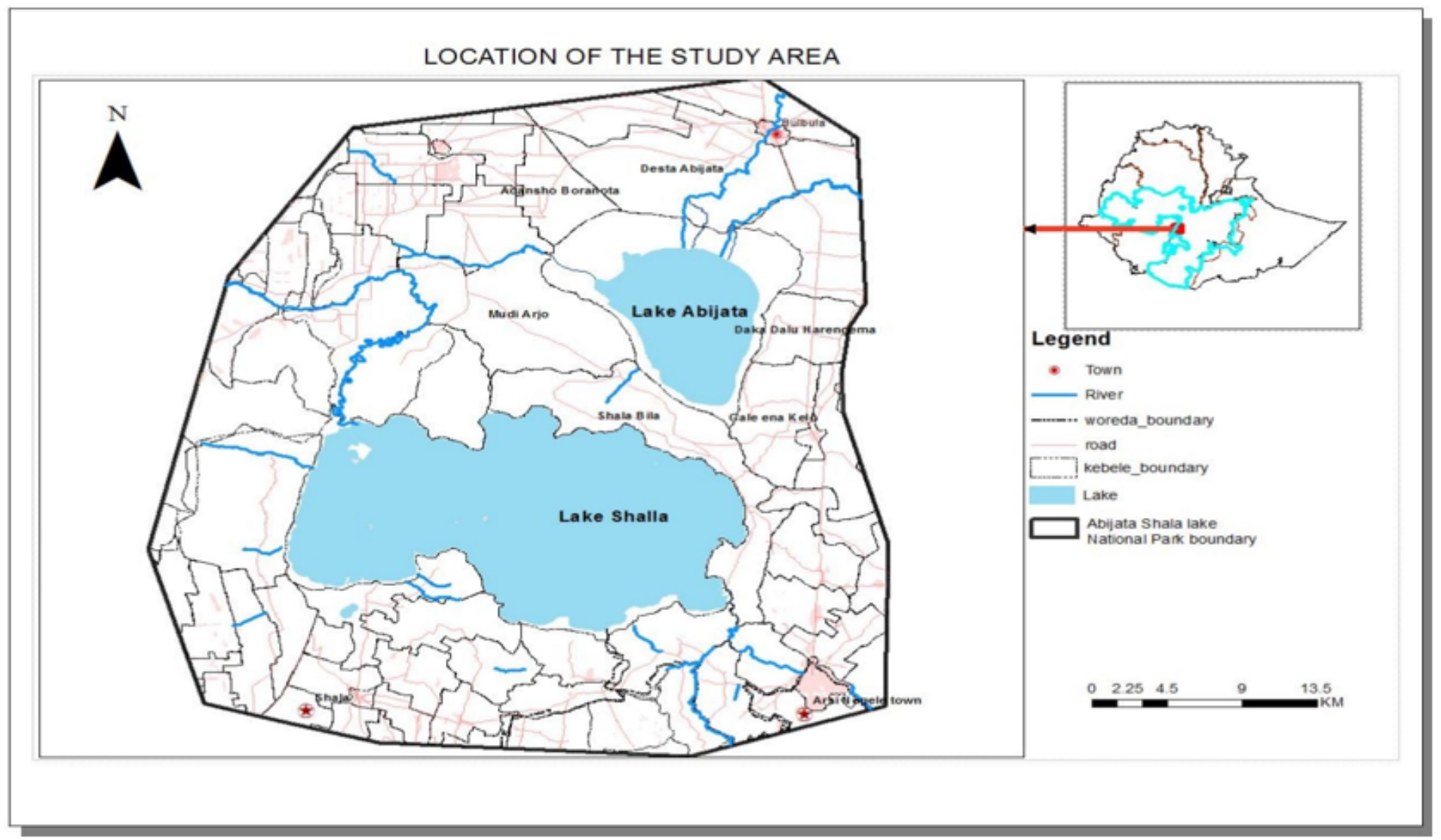

Figure 1

Location of the Study Area 


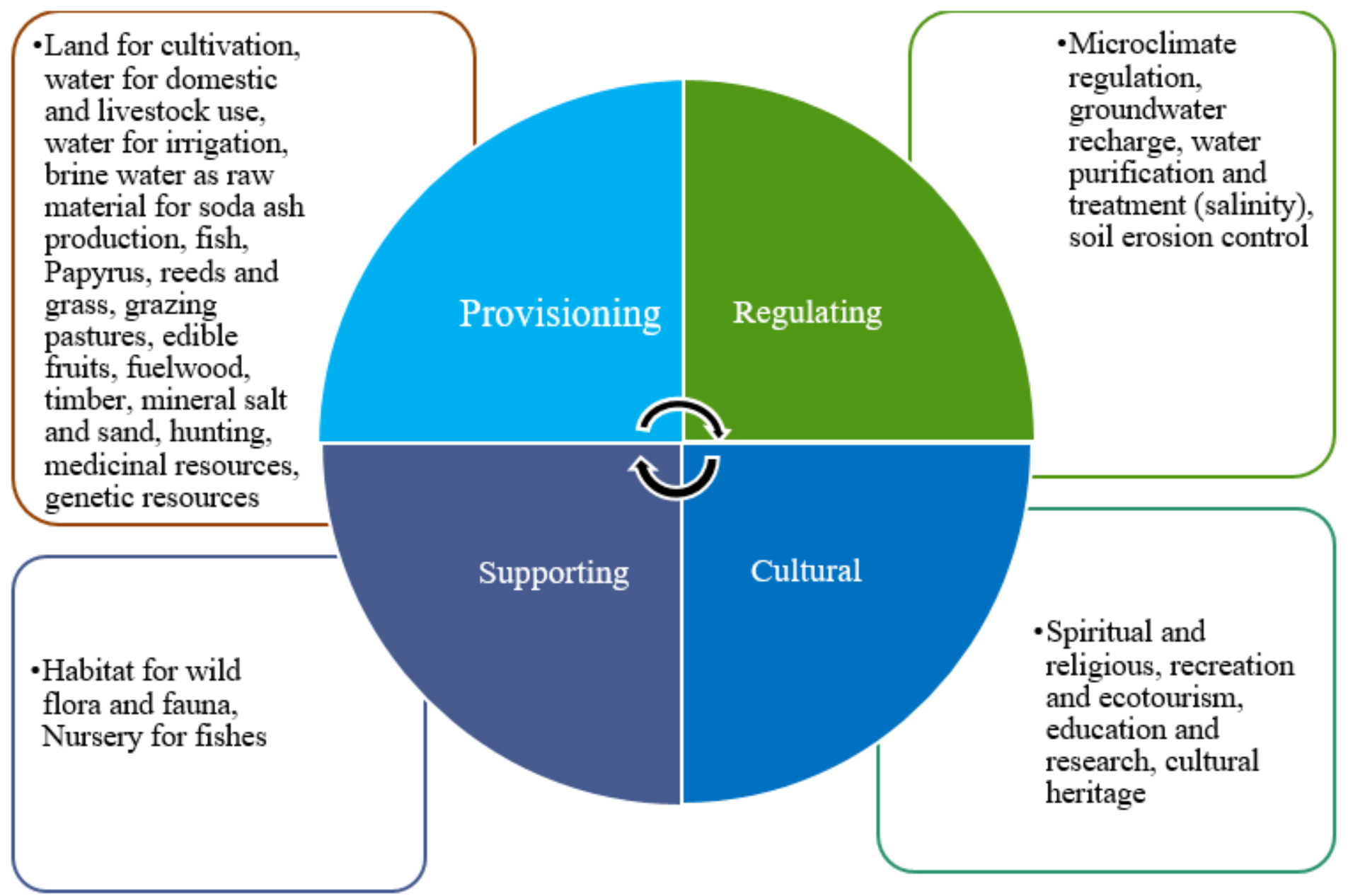

Figure 2

ESs identified in the study area (pre- 1991).

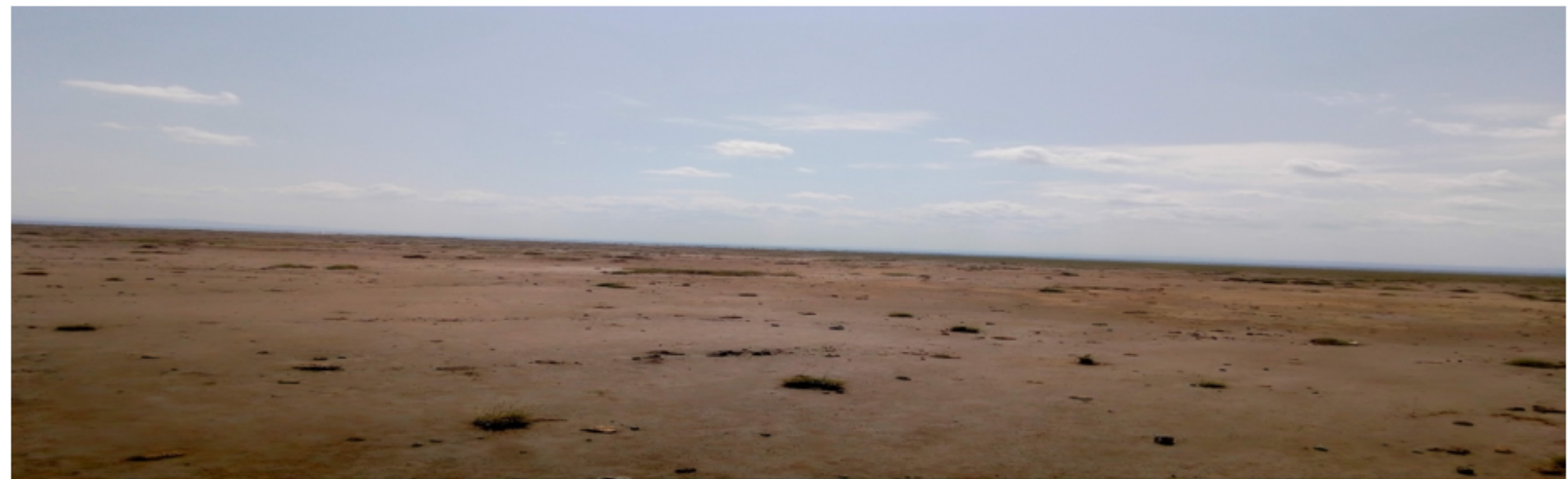

Figure 3

Field Photo by Researcher (2020) 


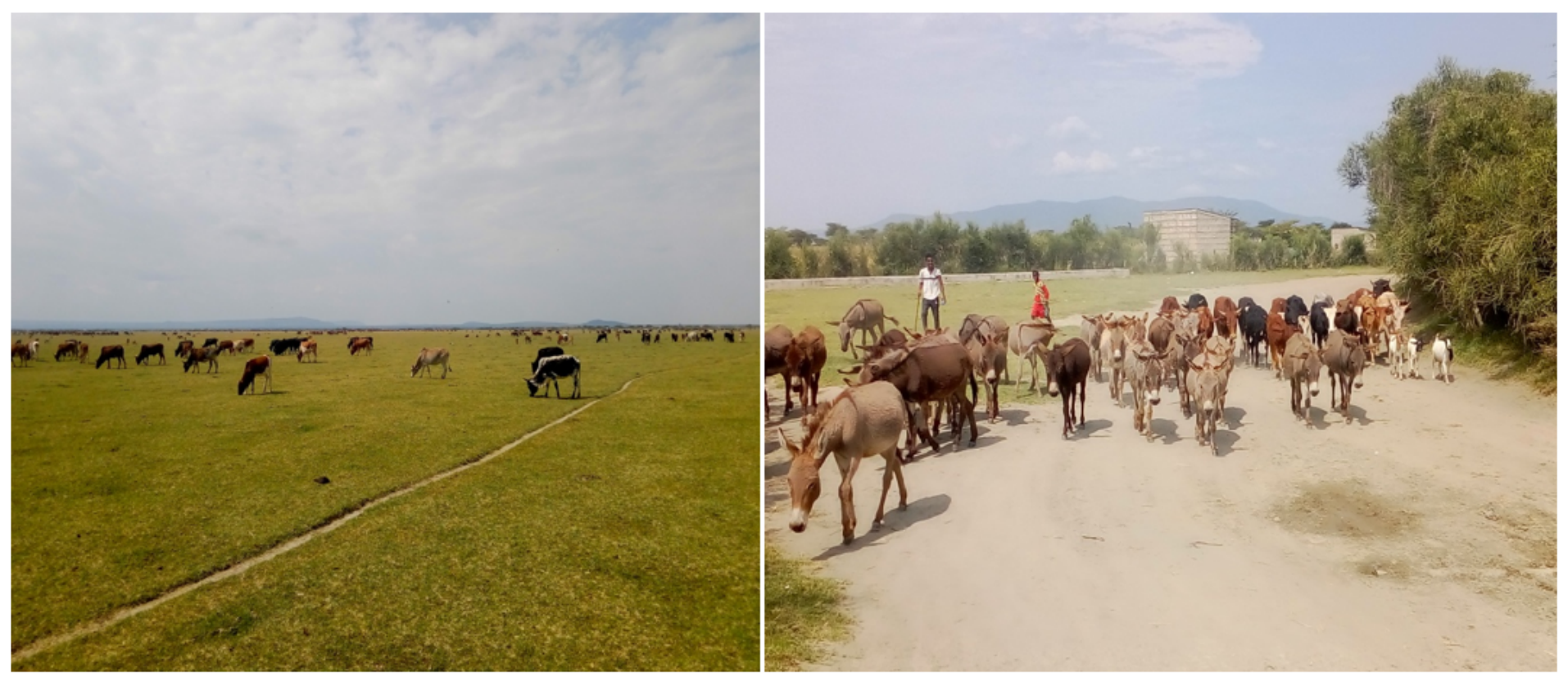

Figure 4

Grazing Area on Shore of Abijata (a), relocation of livestock to the AW (b) (Site Photo by the Researcher, 2020)

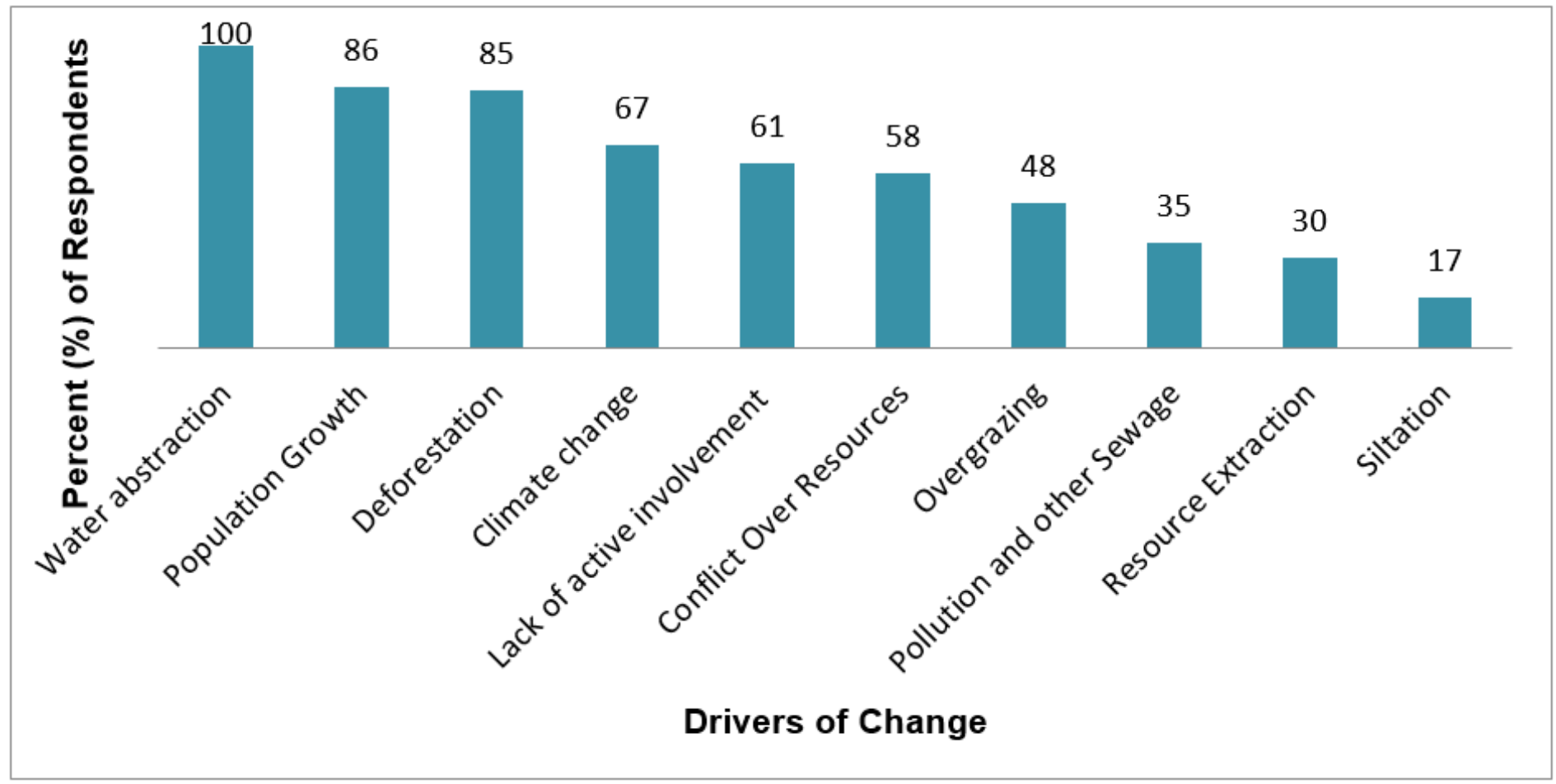

Figure 5 
Drivers of Changes in ESs as determined by the FGD participants of the study site (Relative rating of the identified drivers in percentage).

\section{Supplementary Files}

This is a list of supplementary files associated with this preprint. Click to download.

- AppendixIII.docx 